\title{
Lettuce production according to different sources of organic matter and soil cover
}

\author{
Maria Aparecida Moreira ${ }^{1}$, Carlos Allan Pereira dos Santos ${ }^{1}$, \\ Ariovaldo Antonio Tadeu Lucas ${ }^{2^{*}}$, Flávio Gabriel Bianchini ${ }^{3}$, Igor Machado de Souza ${ }^{3}$, \\ Pedro Roberto Almeida Viégas ${ }^{1}$
}

${ }^{1}$ Department of Agronomy, Federal University of Sergipe, Sergipe, Brazil

${ }^{2}$ Department of Agricultural, Federal University of Sergipe, Sergipe, Brazil; *Corresponding Author: aatlucas@ufs.br

${ }^{3}$ University of Lavras, Minas Gerais, Brazil

Received 11 October 2013; revised 12 January 2014; accepted 26 January 2014

Copyright (c) 2014 Maria Aparecida Moreira et al. This is an open access article distributed under the Creative Commons Attribution License, which permits unrestricted use, distribution, and reproduction in any medium, provided the original work is properly cited. In accordance of the Creative Commons Attribution License all Copyrights (c) 2014 are reserved for SCIRP and the owner of the intellectual property Maria Aparecida Moreira et al. All Copyright (c) 2014 are guarded by law and by SCIRP as a guardian.

\section{ABSTRACT}

Lettuce (Lactuca sativa L.) is one of the leading vegetables produced by farmers in the Itabaiana region, and thus it is important to study means of sustainable management for the crop. The objective of this work was to evaluate the behavior of lettuce with different sources of organic matter and soil cover. Therefore, it was chosen to cultivate Veronica. The experiment was carried out in the experimental field plot of Project Small Farmer-Great Entrepreneur in the municipality of Itabaiana-SE, in 2010. The design was a randomized block design with four replications, with treatments consisting of five sources of organic matter (organic compost, chicken manure, cattle manure, sheep manure, and castor bean) and a control (no fertilizer), all with and without mulch, totaling 12 treatments. We evaluated the characteristics of plant diameter, plant height, fresh and dry root and shoot matter. We also evaluated the influence on the temperature and soil water tension. All productivity characteristics valuated showed the significant interaction between the type of fertilizer and the mulch, except for root dry weight, where only organic manure was a significant factor. When soil mulch was used, the best source of organic matter for growing lettuce was chicken manure, and in the impossibility of using this cover, we recommend the use of organic compost as a source of organic matter, as it showed the best result in the absence of coverage. The cover age also showed good results in relation to a tem- perature that promoted lower soil water tensions.

\section{KEYWORDS}

Lactuca sativa L.; Organic Fertilizer; Soil Water Tension

\section{INTRODUCTION}

The lettuce is one of the most important commercial vegetables and the major consumption in the world. In Brazil, lettuce is the major vegetable produced and commercialized. It is consumed as salad. And in fast food for this reason, it is the crucial importance carries out researchers with new techniques to optimize the production and guarantee the environmental sustainability in agricultural areas. Northwest of Brazil has a semiarid climate where lettuce has been coming grown, in particular at Itabaiana, Sergipe State due to acceptance.

Every day increases the concern with food intake that received excessive chemicals application, since it is known that some chemical molecules when consumed outside the prudential limits cause disease in the short and long term, and vegetable lettuce actually is consumed in natura, steadily increasing consumers' concern with how it is cropped, and parallel to this fact that there is an increasing demand for organic products.

The use of mineral fertilizers in lettuce growth is a common agricultural practice that brings satisfactory results in terms of yield, however, consumers health, production cost and product quality should be considered. Currently, organic fertilizers are used in lettuce production from various sources, which provide improvement 
physical and chemical soil properties [1], reduce needs for mineral fertilizers. Organic matter added to the soil as organic fertilizers form, according to the waste degree of decomposition, can take effect immediately in the soil and/or residual effect by means of a slower process of decomposition [2].

The application of organic fertilizers in lettuce cause increases in production and nutrient content in plants [3]. Study point that different doses of compost $(0,22.8,45.6$, 68.4 and $91.2 \mathrm{t} \cdot \mathrm{ha}^{-1}$ ) reduce dry matter and soluble sugars, especially when increase organic doses compound, while the fresh matter production raises [4].

Knowing that leafy vegetables respond well to organic manure results obtained from an experiment with arugula and lettuce, concluded that organic matter mineralization contributed for nutrients to plants supplying their needs during development, because the area was managed with organic practices about five years [5]. The effect of different organic compounds in lettuce vegetable can cause lower yields and this is attributed to organic compounds insufficiently mineralized to feed plants.

Another research lead with lettuce concluded that the use of 150 grams of organic compound per plot of different agricultural waste produced no significant difference in fresh weight leaves and stems [6].

Organic compound has a positive effect on plant fresh weight as pointed by an experiment, which tested three doses (30, 60 and $120 \mathrm{t} \cdot \mathrm{ha}^{-1}$ ) and three different compositions. It could be observed that the compound bean straw increased the plant fresh weight and the amount of $\mathrm{N}, \mathrm{K}, \mathrm{Ca}, \mathrm{Mg}, \mathrm{Cu}, \mathrm{Fe}$ and $\mathrm{Zn}$ in lettuce plants [7].

Adopting techniques such as ground cover brings benefits not only to the physical, chemical and biological soil characteristics, but also acts as a barrier that reduces the growth and development of weeds because the soil cover prevents light passage, which hinders weeds germination that are present in the soil. Moreover, the ground cover aid soil to retain water, keeping it wet and resulting irrigations intervals more spaced between days.

It also acts as an agent insulator, preventing sharp fluctuations in soil temperature and contributing to less evaporation of water stored with better use of the water content in the soil by plants [8], in addition to providing greater aeration and less soil compaction [9].

The use of cover crops for lettuce has proven increasing production and product quality. However, for using noncommercial cover ground, it must be available in local of cultivation to become viable alternative and it must be evaluated.

Soil cover is a technique commonly utilized in the world and some regions in Brazil researchers keep looking for more information to improve production. In Minas Gerais, the soil cover with coffee pods had better performance compared with synthetic plastic in crops characteristics. This result is important, especially for the southern region of Minas, because, in this area, there is a large availability of coffee pods [10]. Indeed cover crops have been improving vegetables production as in some cases cover ground with grass and double-sided polyethylene produced the highest fresh weight, diameter and number of leaves, but it is recommended to use natural material to cover soil during periods of high temperatures and the use of polyethylene in times of low temperatures concluded the authors [11]. Plant residues also contribute as a reserve of nutrients [12].

The evaluation of influence of various types of ground cover on the lettuce yield and states that the roofs with sugarcane bagasse and rice straw provided greater weight gains of plants, 710.0 and 669.5 grams, respectively, when compared to bare ground without weeding treatment (355.6 g) and treatment which used transparent plastic (280.4 g) [13]. Also, it was observed that the coverage provided higher average number of leaves and fresh weight compared with the control (bare soil) [14]. This study aimed to evaluate the effect of different sources of organic matter and soil cover in the production characteristics of lettuce, soil temperature and water tension.

\section{MATERIAL AND METHODS}

\subsection{Experimental Site}

This work was conducted from November of 2010 to January 2011, at the experimental Project Small Producer Great Entrepreneur from Federal University of Sergipe, in the municipality of Itabaiana, located at latitude $10^{\circ} 41^{\prime} 11^{\prime \prime}$ and Longitude $37^{\circ} 25^{\prime} 37^{\prime \prime}$, with transitional climate between the semi-arid and semi-humid, with average annual temperature of $24.7^{\circ} \mathrm{C}$ and average rainfall of $858.5 \mathrm{~mm}$. A cultivar Veronica was used to cultivate the crisp group. The seedlings were grown in the greenhouse where they used plastic trays with 162 cells and commercial substrate, keeping the trays in a greenhouse in irrigation system used by microsprinkler.

Before beginning the experiment soil samples had been collected using an auger at $0-20 \mathrm{~cm}$ depth for performing chemical and physical analysis. The analyzes were performed at the Laboratory of Soil analysis at the Federal University of Lavras, whose results showed the following values: $\mathrm{pH}=7.7,0.6 \mathrm{Dag} / \mathrm{kg}$ organic matter, $83.7 \mathrm{mg} / \mathrm{dm}^{3}$ P, $50 \mathrm{Mg} / \mathrm{dm}^{3} \mathrm{~K}$; cmolc/dm ${ }^{3} 1.9 \mathrm{Ca}, 2.9$ $\mathrm{Mg}$ cmolc/ $/ \mathrm{dm}^{3} ; 0.7 \mathrm{cmolc} / \mathrm{dm}^{3} \mathrm{H}+\mathrm{Al}, 5.6$ par CTC and $87.8 \%$ base saturation (V). Organic matter sources used also were analyzed and presented the following results; $1.95 \%$ of N-total, $16.9 \mathrm{~g} / \mathrm{kg}$ of $\mathrm{P}$ and $16.9 \mathrm{~g} / \mathrm{kg}$ of $\mathrm{K}$ for poultry manure; $1.05 \%$ of N-total, $2.81 \mathrm{~g} / \mathrm{kg}$ of $\mathrm{P}$ and 4.5 $\mathrm{g} / \mathrm{kg}$ of K dung sheep; $3.07 \%$ of N-total, $3.74 \mathrm{~g} / \mathrm{kg}$ of $\mathrm{P}$ and $9.75 \mathrm{~g} / \mathrm{kg}$ of $\mathrm{K}$ for organic compound and $1.38 \%$ of 
N-total, $1.98 \mathrm{~g} / \mathrm{kg}$ of P and $8.25 \mathrm{~g} / \mathrm{kg}$ of K for cattle manure.

\subsection{Experimental Design}

The transplant was done when the seedlings were with four true leaves. The experimental design was a randomized factorial block $6 \times 2$. The first factor was composed of different types of organic matter: cattle manure (CM), dung sheep (DS), poultry manure (PM), organic compound (OC), castor bean (CB) and control (without addition organic matter: T). For the second factor was considered with (GC) and without (WGC) ground cover, totaling 12 treatments: CM/GC, CM/WGC, DS/GC, DS/ WGC, PM/GC, PM/WGC, OC/GC, OC/WGC, CB/GC, CB/WGC, T/GC, TWGC.

For ground cover was used Pennisetum purpureum Schumach as natural soil cover. Doses of $30 \mathrm{t} / \mathrm{ha}$ of organic fertilizer sources were applied in all treatments. During the crop cycle were performed hoeing, the first 15 days and the second at 30 days after transplantation. Irrigation was done daily for two periods, in the early morning and late afternoon using the micro system. After transplanting, tension meters were installed for soil water tension readings through digital device. The readings were taken daily in the morning before the first irrigation.

To perform temperature readings a digital thermometer had been used. The readings were always taken weekly at a central useful plot. Evaluations were made 43 days after transplanting and considering as reference the treatment with poultry manure, where plants showed early bolting. The plants were harvested and the same day, were conducted assessments as follow: shoot and root fresh weight, leaves number, diameter of the head. For measuring these characteristics were adopted 5 plants per plot from central plants line of each plot. After that, the plants were placed in paper bags, separating the shoot and root, and put to forced circulation oven at $60^{\circ} \mathrm{C}$ for 6 days and then removed for weighing dry. Data were subjected to the analysis of variance and means were compared by the Scott Knott test.

\section{RESULTS AND DISCUSSION}

Statistics analyses showed that for plants characteristics significant interaction for both factors, except for root dry weight, where only organic fertilizer factor was significant (Table 1).

In relation to the diameter of lettuce head, when utilized soil cover could be observed a different behavior among organic fertilizer sources and poultry manure had higher average with $31.65 \mathrm{~cm}$, followed by treatment with organic compost $(27.03 \mathrm{~cm})$ and sheep manure $(26.32 \mathrm{~cm})$. The manure and castor bean showed the worst performers presenting averages $20.82 \mathrm{~cm}$ and
$23.50 \mathrm{~cm}$ respectively, statistically equal to the control (Table 1). A study pointed out value of lettuce head of $26 \mathrm{~cm}$ when organic compound, cattle manure and humus were used; this value is statistically similar to the value found in this work when mineral fertilizer was applied [15]. Other research assessing the effect of different organic residues on lettuce yield observed that the employ of poultry manure combined with chemical fertilizer resulted in the diameter lettuce head increasing, also they found that the double recommended dose of poultry manure satisfactory substitute for mineral fertilize, when handle correctly [16].

A positive response had observed on the heads diameter to the lettuce culture when they increase doses of organic compound, obtaining larger and heavier plants in the plots with organic compound incorporated [17].

The poultry and dung sheep had significant improvement when coverage was put in service. The other treatments did not differ statistically for this variable.

Regarding the leaves number (Table 1) when made use of mulching treatment with poultry manure showed different behavior, nevertheless poultry manure presented the best result followed by treatment with organic compound. Treatments where cattle manure, castor bean and dung sheep were utilized as sources the results were statistically equal to the control. Poultry manure also favored leaves number characteristic with soil coverage treatment. A field studied carried out applying poultry manure, compost and mineral fertilization find out that there were not a significant interaction between treatment and planting date to leaf number, but an experiment with different organic matter sources incorporated to soil showed number leaves varying from 24.1 to $29.8[15,18]$.

Table 1. Means of diameter and leaves number of lettuce vegetables in function of organic matter and soil cover.

\begin{tabular}{ccccc}
\hline & \multicolumn{2}{c}{ Diameter $(\mathrm{cm})$} & \multicolumn{2}{c}{ Leaves Number } \\
\cline { 2 - 5 } Treatment & \multicolumn{4}{c}{ Groud Cover } \\
\cline { 2 - 5 } & Without & With & Without & With \\
\cline { 2 - 5 } P.M. & $24.54 \mathrm{aB}$ & $31.65 \mathrm{aA}$ & $12.62 \mathrm{bB}$ & $26.12 \mathrm{aA}$ \\
C.M. & $25.30 \mathrm{aA}$ & $20.82 \mathrm{cA}$ & $16.60 \mathrm{aA}$ & $11.24 \mathrm{cB}$ \\
O.C. & $28.08 \mathrm{aA}$ & $27.03 \mathrm{bA}$ & $20.51 \mathrm{aA}$ & $20.71 \mathrm{bA}$ \\
C.B. & $24.16 \mathrm{aA}$ & $23.50 \mathrm{cA}$ & $13.68 \mathrm{bA}$ & $13.68 \mathrm{cA}$ \\
D.S. & $19.15 \mathrm{bB}$ & $26.32 \mathrm{bA}$ & $10.02 \mathrm{bB}$ & $16.57 \mathrm{cA}$ \\
T. & $24.50 \mathrm{aA}$ & $22.22 \mathrm{cA}$ & $12.50 \mathrm{bA}$ & $11.10 \mathrm{cA}$ \\
CV (\%) & \multicolumn{3}{c}{10.18} \\
\hline
\end{tabular}

Means followed by the same letters, lowercase and uppercase letters in the columns in the rows are not statistically different by the Scott-Knott test at 5\%. P.M.: poultry manure; C.M.: cattle manure; O.C.: organic compost; C.B.: castor bean; D.S.: dung sheep; T.: no fertilization (testimony). 
Under organic cultivation lettuce behavior had evaluated and it noted that the lettuce leaves yield may be related to the functions that organic fertilizers have on the physical, chemical and biological soil properties, once the organic fertilizers exhibit conditioning effects and increase soil capacity to story nutrients for plant development [19].

Lowest number of leaves can be caused by high temperature and light during the period that performed the experiment, which also resulted in lower vegetative cycle [20].

The use of poultry manure associated with soil cover provided the best plant fresh matter production (Table 2), statistically similar to the organic compound, with averages of $254.3 \mathrm{~g}$ and $178.86 \mathrm{~g}$ respectively. The other organic matter sources presented no significant difference in the practice of soil cover crops. Adding organic matter sources in lettuce production can induce an increase in fresh weight when using poultry litter as a source of fertilizer [20]. This fact can be stated by the work where organic matter substitute mineral fertilization with fresh matter value around 194.1 to $222.0 \mathrm{~g}$, the sources were organic compound, cattle manure and humus [15]. It corroborates the results reported on this experiment with conventional fertilization. After these results came those treatments where dung sheep and castor bean worked as organic matter sources. For this characteristic, the cattle manure achieved the same testimony behavior, which can be explained by the origin of the cattle manure and may have an immediate or residual according to the degree of decomposition of the waste [21].

The effect of coverage had significant differences between treatments with poultry manure and dung sheep where coverage soil provided considerable increase for this characteristic.
To root fresh weight organic compound and poultry manure were higher when using mulch and plant dry mass, but the poultry manure was superior to the others. Without ground cover all treatments were statistically equal for these two characteristics (Table 2).

Similar results were discovered when assessing the production of lettuce in an organic system using cover crops, where the production of fresh matter had an increase when grass had utilized as soil cover [11].

To dry root there was not significant interaction between the factors studied. Only the organic matter source factor was significant where the poultry manure and organic compost showed the best results.

Table 3 shows the air and the soil temperatures during the experiment development. In all treatments the soil temperature remained higher than the air temperature.

Working with soil cover (organic mulch and plastic) results obtained can be associated to the occurrence of higher temperatures caused by covering the soil with plastics in comparison with other types of coverage and observed that the soil temperature average covered with rice paddy was equal to uncovered soil, $23.9^{\circ} \mathrm{C}$ [22]. This statement agree with similar results found, which reported the effect of plastic to increase the soil temperature at levels that affect plant metabolism by interfering with their growth and development [23].

It can be noted that there was a trend of increasing temperature in treatments without mulch. The temperature is influenced by the types of coverage and it also influenced the amount of existing weeds [24].

The treatment which castor bean had been put had the highest temperature even when used mulch (Table 3).

In relation to soil water tension was no change to the treatments studied (Figure 1), however there was a trend of treatments ground cover present readings lower, thus

Table 2. Means of fresh and dry weight of shoot and root.

\begin{tabular}{|c|c|c|c|c|c|c|}
\hline \multirow[t]{3}{*}{ Treatment } & \multicolumn{2}{|c|}{ Plant Fresh Weight (g) } & \multicolumn{2}{|c|}{ Root Fresh Weight (g) } & \multicolumn{2}{|c|}{ Plant Dry Weight (g) } \\
\hline & \multicolumn{6}{|c|}{ Soil Cover } \\
\hline & Without & With & Without & With & Without & With \\
\hline P.M. & 55.08 bB & $254.30 \mathrm{aA}$ & $3.93 \mathrm{aB}$ & $12.20 \mathrm{bA}$ & $5.01 \mathrm{aB}$ & $18.46 \mathrm{aA}$ \\
\hline C.M. & $103.32 \mathrm{aA}$ & $58.74 \mathrm{cA}$ & $8.33 \mathrm{aB}$ & 3.58 cA & $8.50 \mathrm{aA}$ & $4.44 \mathrm{bA}$ \\
\hline O.C. & $134.43 \mathrm{aA}$ & $178.86 \mathrm{aA}$ & $9.13 \mathrm{aA}$ & $11.68 \mathrm{bA}$ & $10.50 \mathrm{aA}$ & $9.76 \mathrm{bA}$ \\
\hline C.B. & 49.93 bA & $97.18 \mathrm{bA}$ & $5.62 \mathrm{aA}$ & $5.50 \mathrm{cA}$ & $5.53 \mathrm{aA}$ & $7.70 \mathrm{bA}$ \\
\hline D.S. & 35.52 bB & $92.62 \mathrm{bA}$ & $3.37 \mathrm{aA}$ & 7.52 cA & $3.46 \mathrm{aA}$ & $7.12 \mathrm{bA}$ \\
\hline $\mathrm{T}$. & 67.18 bA & $42.00 \mathrm{cA}$ & $4.81 \mathrm{aA}$ & 3.92 cA & $5.50 \mathrm{aA}$ & $3.68 \mathrm{bA}$ \\
\hline CV (\%) & \multicolumn{2}{|c|}{19.01} & \multicolumn{2}{|c|}{22.08} & \multicolumn{2}{|c|}{23.49} \\
\hline
\end{tabular}

Means followed by the same letters, lowercase and uppercase letters in the columns in the rows are not statistically different by the Scott-Knott test at 5\%. P.M.: poultry manure; C.M.: cattle manure; O.C.: organic compost; C.B.: castor bean; D.S.: dung sheep; T.: no fertilization (testimony). 
Table 3. Soil temperatures and mean air temperature in function of organic matter and soil coverage.

\begin{tabular}{cccccc}
\hline Date & $12 / 21$ & $12 / 28$ & $12 / 30$ & $01 / 06$ & $01 / 07$ \\
\hline Treatment & 26.7 & 25.6 & 26.9 & 25.6 & 25.6 \\
\hline CM/WGC & 31.2 & 32.5 & 29.1 & 28.0 & 29.7 \\
CM/GC & 30.8 & 32.0 & 29.1 & 27.8 & 29.9 \\
DS/WGC & 31.1 & 31.4 & 28.9 & 27.8 & 29.4 \\
DS/GC & 30.7 & 31.1 & 28.7 & 28.0 & 29.0 \\
PM/WGC & 31.4 & 32.5 & 29.7 & 27.8 & 29.8 \\
PM/GC & 30.8 & 31.5 & 28.6 & 27.9 & 29.5 \\
OC/WGC & 31.8 & 32.3 & 29.4 & 28.8 & 29.3 \\
OC/GC & 30.9 & 30.7 & 28.2 & 28.5 & 28.8 \\
CB/WGC & 33.2 & 33.5 & 30.2 & 28.3 & 29.4 \\
CB/GC & 31.6 & 31.9 & 30.3 & 28.2 & 28.4 \\
T/WGC & 31.1 & 32.2 & 28.7 & 28.5 & 29.1 \\
T/GC & 31.2 & 31.7 & 29.3 & 2 \\
\hline
\end{tabular}

*Mean daily temperature.

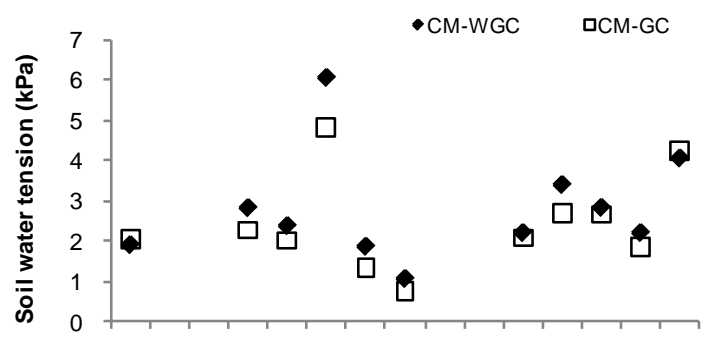

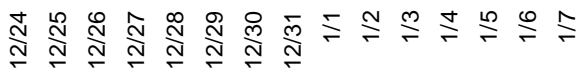

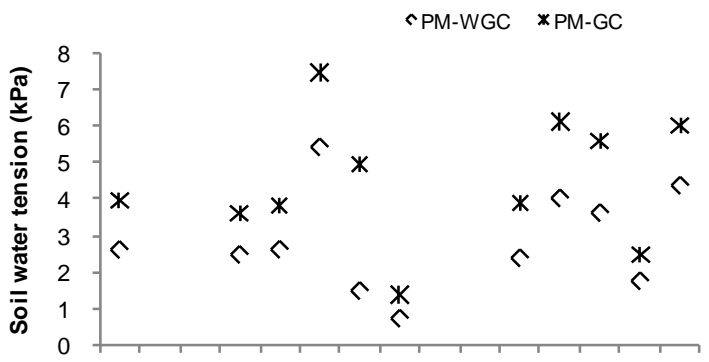

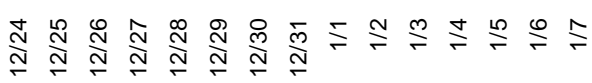

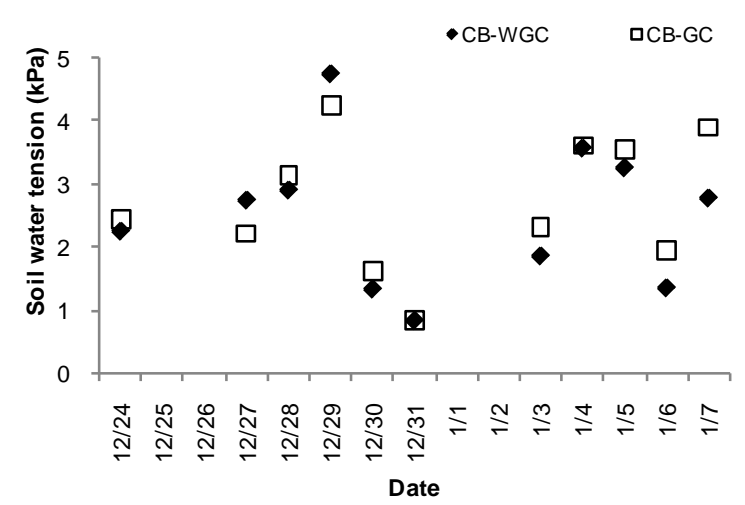

$\triangle D S-W G C \quad \times D S-G C$

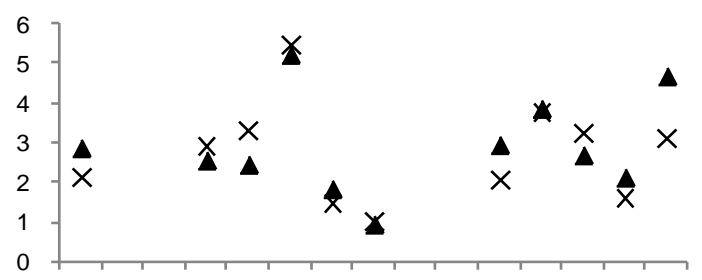

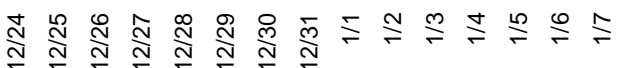

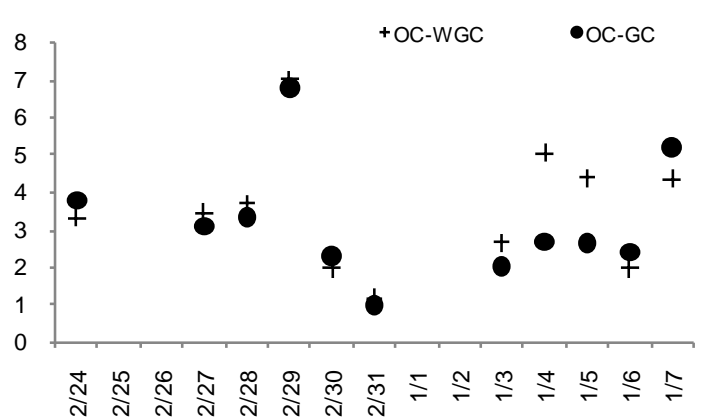

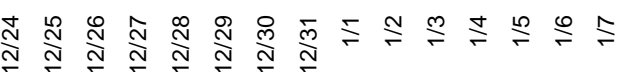

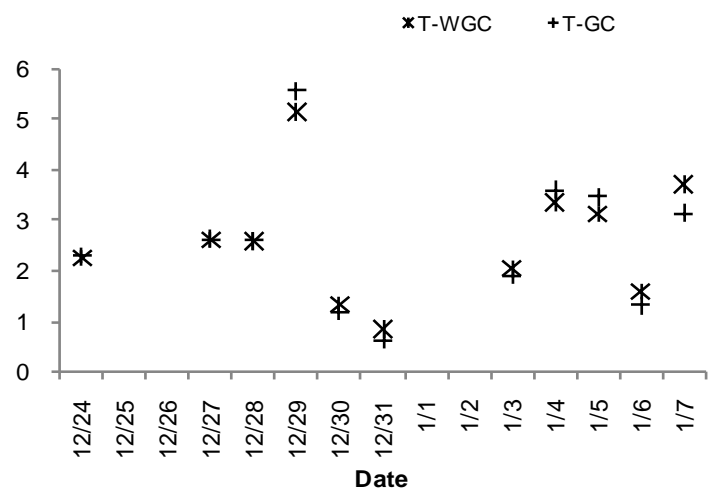

Figure 1. Variation of soil water tension in the treatments without coverage (WGC) and coverage (CG) soil. 
having an influence on coverage of water tension in the soil and consequently the capacity to retain water in the soil.

When mulching was utilized the treatment with organic compost and poultry manure had higher soil water tension (Figure 1). The treatment which was not used any source of organic matter showed the lowest values of soil water tension when used mulch, thus showing the influence of cover and organic matter in the soil water tension. Whenever evaluated land cover influence water retention and found out soil water tension range in the treatment without mulch around $4 \mathrm{kPa}$ [25].

This research presented values of soil water tension within the range quoted [26] which determined that for a sandy soil should be irrigated when the values are between 5 - $10 \mathrm{kPa}$.

Experiment lead in the field showed that the lower soil water tension for lettuce fresh matter had the largest commercial product quality, highlighting the importance of water supply as one of the major factor to obtain the highest yield when irrigations is distributed more frequently throughout the crop cycle [27].

\section{CONCLUSION}

The findings of the present paper suggest that the poultry manure spreaded on the soil surface as mulch is the best source of organic matter for lettuce cultivation. Therefore, the growers can use this organic compound as mulch when other materials are in shortage. The use of soil coverage presented good results in relation to soil temperature as well as water retention.

\section{REFERENCES}

[1] Kiehl, J.E. (1985) Organicfertilizers. Agronômica Ceres, Piracicaba.

[2] Vidigal, S.M., Sediyama, M.A.N., Garcia, N.C.P. and Matos, A.T. (1997) Lettuce yield growth with different organic compounds and swine effluent. Horticultura Brasileira, 15, 35-39.

[3] Rodrigues, E.T. and Casali, V.W.D. (1999) Yield and nutrient concentration in lettuce as a function of organic and mineral manuring. Horticultura Brasileira, 17, 125128. http://dx.doi.org/10.1590/S0102-05361999000200010

[4] Santos, R.H.S., Casali, V.W.D., Conde, A.R. and Miranda, L.C.G. (1994) Let tuce quality growth with organic compound. Horticultura Brasileira, 12, 29-32.

[5] Oliveira, E.Q., Souza, R.J., Cruz, M.C.M., Marques, V.B. and França, A.C. (2010) Lettuce and arugula yield in consorted systems under organic and mineral fertilization. HorticulturaBrasileira, 28, 36-40. http://dx.doi.org/10.1590/S0102-05362010000100007

[6] Nakagawa, J., Büll, L.T., Prochnow, L.I. and Villas Bôas, R.L. (1992) Organic compounds effects in lettuce (Lac- tuca sativa L.) crop: Series I. Científica, 20, 173-180.

[7] Villas Bôas, R.L., Passos, J.C., Fernandes, D.M., Büll, L.T., Cezar, V.R.S. and Goto, R. (2004) Doses effects and organic compounds types in lettuce crop in two soils under protect environment. Horticultura Brasileira, 22, 28-34.

http://dx.doi.org/10.1590/S0102-05362004000100006

[8] Bizari, D.R., Matsura, E.E., Roque, M.W. and de Souza, A.L. (2009) Water consumption and yield of irrigated common bean in tillage and conventional tillage systems. Ciência Rural, 39, 2073-2079.

http://dx.doi.org/10.1590/S0103-84782009000700018

[9] Da Araújo, R.C., de Souza, R.J., da Silva, A.M. and Alvarenga, M.A.R. (1993) Effects of soil mulch on garlic crop (Allium sativum L) crop. Ciência e Prática, 17, 228233.

[10] Andrade Jr., V.C., Yuri, J.E., Nunes, U.R., Pimenta, F.L., Matos, C.S.M., Florio, F.C.A. and Madeira, D.M. (2005) Use of cover types for lettuce crop. Horticultura Brasileira, 23, 899-903.

[11] Rodrigues, D.S., Nomura, E.S. and Garcia, V.A. (2009) Yield and nutrient concentration in lettuce, depending on the organic and mineral fertilizers. Revista Ceres, 56, 332335.

[12] Rosolem, C.A., Calonego, J.C. and Foloni, J.S.S. (2003) Potassium leaching of straw cover crops depending on the amount of rain. Revista Brasileira de Ciência do Solo, 27, 355-362.

http://dx.doi.org/10.1590/S0100-06832003000200015

[13] Andreani Jr., R. and Galbiati Neto, P. (2003) Evaluation influence of death cover under lettuce crop development at Fernandópolis-SP region. Horticultura Brasileira, 21, 2.

[14] Carvalho, J.E., Zanella, F., Mota, J.H. and Lima, A.L.S. (2005) Soil mulching cover in lettuce crop in Ji ParanáRO. Ciência e Agrotecnologia, 29, 935-939. http://dx.doi.org/10.1590/S1413-70542005000500003

[15] Batista, M.A.V., Vieira, L.A., de Souza, J.P., de Freitas, J.D.B. and Bezerra Neto, F. (2012) Effect of different sources of fertlization on lettuce crop in Igaratu-CE municipality. Revista Caatinga, Mossoró, 25, 8-11.

[16] de Almeida Neto, J.X., Carneiro, I.F. and Pereira, A.V. (1990) Effect of different organic wastes in the development and productivity of lettuce (Lactuca sativa L.). Anais Escola Agronomia e Veterinária, 20, 1, 45-51.

[17] Pimentel, M.S., Lana, A.M.Q. and De-Polli, H. (2008) Commercial quality of lettuce and carrot consortium and fertilized with organic compound. Embrapa Agrobiologia, Boletim de Pesquisa de Desenvolvimento, Seropédica.

[18] de Freitas, M.E., Bono, J.A.M., Pedrinho, D.R., Chermouth, K.S., Yamomoto, C.R. and de Vidis, R.Y. (2009) Use of organics compounds as fertilization for the culture of lettuce. Agrarian, 2, 41-52.

[19] de Oliveira, C.A.P. and de Souza, C.M. (2003) Influence of mulch on moisture, weed pressure and berry borer rhizome (Cosmopolites sordidus) in an orchard of banana (Musa spp.). Revista Brasileira de Fruticultura, Jaboticabal, 25, 345-347. 
[20] Porto, V.C., de Negreiros, M.Z., Neto, F.B. and Nogueira, I.C.C. (1999) Sources and rates of organic matter on lettuce production. Revista Caatinga, Mossoró-RN, 12, 711.

[21] Vidigal, S.M., Ribeiro, A.C., Casali, V.W.D. and Fontes, L.E.F. (1995) Response of lettuce (Lactuca sativa L.) to the residual effect of organic fertilization II-Test greenhouse. Revista Ceres, Viçosa, 42, 89-97.

[22] Zizas, G.B., Seno, S., Faria Jr., M.J.A. and Seleguini, A. (2002) Effect of mulching on yield and quality of six lettuce cultivars and soil-cultivar interactions in the period May-June 2001. XLII Brazilian Congress of Vegetables Crops, Brasília, 28 July 2002-2 August 2002, pp. 270273.

[23] Chaves, S.W.P., Medeiros, J.F., Negreiros, M.Z. and Nagão, E.O. (2003) Yield of lettuce as a function of land cover and irrigation frequency. XLIII Brazilian Congress of Vegetables Crops, Brasília, 27 July 2003-1 August 2003.

\section{ABBREVIATIONS}

Abbreviations of treatments names used at the experiment.

Cattle Manure (CM), Dung Sheep (DS), Poultry Manure (PM), Organic Compound (OC), Castor Bean (CB) and Testimony (without addition organic matter: $\mathrm{T}$ ). For the combination between sources of organic matter and ground cover the abbreviations are: With Ground Cover (GC) and Without Ground Cover (WGC); Cattle Manure With Ground Cover (CM/GC), Cattle Manure Without Ground Cover (CM/WGC),
[24] Moura Filho, E.R., Rodrigues, A.P.M.S., Freire, J.O., Dantas, M.M., Bergamo, G.C. and Freitas, F.C.L. (2010) Ground cover in weed management in lettuce. XXVII Brazilian Congress of Science of Weed, Centro de Convenções, Ribeirão Preto, 19-23 July 2010, 667-671.

[25] Lima, M.E. (2007) Evaluation of the performance of the lettuce (Lactuca sativa) grown in an organic system of production under different irrigation and soil covers. Universidade Federal Rural do Rio de Janeiro, Instituto de Agronomia, Curso de Pós-Graduação em Fitotecnia, Seropédica.

[26] Carrijo, O.A., Marouelli, W.A. and da Silva, H.R. (1999) Water management in vegetable production under protected cultivation. Informe Agropecuário. Belo Horizonte, 20, 45-71.

[27] Santos, S.R. and Pereira, G.M. (2004) Behavior of the American type lettuce under different soil water tensions in greenhouse. Engenharia Agrícola, Jaboticabal, 24, 569-577.

Dung Sheep With Ground Cover (DS/GC), Dung Sheep Without Ground Cover (DS/WGC), Poultry Manure With Ground Cover (PM/GC), Poultry Manure Without Ground Cover (PM/WGC), Organic Compound With Ground Cover (OC/GC), Organic Compound Without Ground Cover (OC/WGC), Castor Bean With Ground Cover (CB/GC), Castor Bean With Ground Cover (CB/WGC), Testimony With Ground Cover (T/GC) and Testimony Without Ground Cover (TWGC). 